\title{
Application of molecular targeted therapies in the treatment of head and neck squamous cell carcinoma (Review)
}

\author{
PAULINA KOZAKIEWICZ and LUDMIŁA GRZYBOWSKA-SZATKOWSKA \\ Department of Oncology, Medical University of Lublin, 20-90 Lublin, Poland
}

Received November 21, 2017; Accepted January 31, 2018

DOI: $10.3892 / \mathrm{ol} .2018 .8300$

\begin{abstract}
Despite the development of standard therapies, including surgery, radiotherapy and chemotherapy, survival rates for head and neck squamous cell carcinoma (HNSCC) have not changed significantly over the past three decades. Complete recovery is achieved in $<50 \%$ of patients. The treatment of advanced HNSCC frequently requires multimodality therapy and involves significant toxicity. The promising, novel treatment option for patients with HNSCC is molecular-targeted therapies. The best known targeted therapies include: Epidermal growth factor receptor (EGFR) monoclonal antibodies (cetuximab, panitumumab, zalutumumab and nimotuzumab), EGFR tyrosine kinase inhibitors (gefitinib, erlotinib, lapatinib, afatinib and dacomitinib), vascular endothelial growth factor (VEGF) inhibitor (bevacizumab) or vascular endothelial growth factor receptor (VEGFR) inhibitors (sorafenib, sunitinib and vandetanib) and inhibitors of phosphatidylinositol 3-kinase/serine/threonine-specific protein kinase/mammalian target of rapamycin. There are also various inhibitors of other pathways and targets, which are promising and require evaluation in further studies.
\end{abstract}

\section{Contents}

1. Introduction

2. Epidermal growth factor receptor

3. Tyrosine kinase inhibitors

4. Vascular endothelial growth factor

5. The PI3K/AKT/mTOR pathway

6. The PD

7. Other potential targeted therapies

8. Conclusion

Correspondence to: Miss Paulina Kozakiewicz, Department of Oncology, Medical University of Lublin, Jaczewskiego 7, 20-90 Lublin, Poland

E-mail:pauliniasta@gmail.com

Key words: head and neck cancer, targeted therapies, epidermal growth factor receptor, vascular endothelial growth factor receptor, tyrosine kinase inhibitors, programmed death receptor

\section{Introduction}

Among head and neck cancers (HNC), the majority, $\leq 90 \%$, comprise of mutations originating in the squamous epithelium of the upper aerodigestive tract (1). Head and neck squamous cell carcinoma (HNSCC) is the seventh most frequently occurring and the ninth most fatal cancer (1). Standard therapies used for treatment of HNSCC have achieved a consistent five-year survival rate ranging from $40-50 \%$ in the past three decades (2). Treatment for the early stage of this disease is a single therapeutic method, including surgery or radiotherapy $(2,3)$. Cure rates of $>90$ and $70 \%$ have been achieved for stage I and II, respectively $(3,4)$. The radical treatment of patients with locally advanced cancer in stage III or IV requires multimodality therapy. At these stages, a surgical treatment is complemented with radiotherapy or chemoradiotherapy, depending on the risk factors for a relapse including: Dubious margin of healthy tissue; poorly differentiated (G3) cancer; and feature pT4 (advanced local disease) or metastases in the regional lymph nodes $(5,6)$. In stage III and IV it is also possible to apply an organ conserving therapy, such as chemo-radiotherapy or targeted therapy using monoclonal antibodies in combination with radiotherapy $(6,7)$; however, the treatment effects are not as satisfactory, compared with the early stages of the disease. Tumor recurrence within two years was $\sim 0 \%$ in patients who were treated for a locally advanced HNC (8). In these cases, the possibility of treatment with salvage surgery or re-irradiation is limited (8). The use of chemotherapy in patients with recurrent or metastatic changes results in response rates ranging from $10-35 \%$ and a median survival of 6-12 months (9). Concurrent radiochemotherapy in the treatment of HNSCC is complicated due to the occurrence of side effects, including mucositis, dermatitits and dysphagia. The treatment is frequently accompanied by leukopenia and thrombocytopenia, which increases the risk of infection or bleeding (4). Following the treatment, the quality of life deteriorated due to late complications including: Sensorineural hearing loss; polyneuropathy caused by chemotherapy or permanent xerostomia; and impaired swallowing (4). Unsatisfactory outcomes of the HNC treatment using standard methods with high toxicity warrant a search for novel therapeutic options. The search for novel therapies is justified by achievements of genetics and molecular biology, which have initiated the development of targeted cancer therapies (10). These treatments have already been successfully used in the 
treatment of other solid tumor types, including colorectal or lung cancer (10). The action of targeted drugs consist of inactivating specific target molecules required for oncogenesis and tumor growth (11).

In the present review, a description of the currently most promising and well-known molecular targeting strategies used in the treatment of advanced head and neck cancers were produced. These treatments target (Table I): i) Epidermal growth factor receptor (EGFR), ErbB1; ii) vascular endothelial growth factor (VEGF) and vascular endothelial growth factor receptor (VEGFR); iii) intracellular signaling pathway components associated with the phosphatidylinositol 3-kinase $(\mathrm{PI} 3 \mathrm{~K}) /$ serine/threonine-specific protein kinase (AKT)/mammalian target of rapamycin (mTOR); and iv) programmed death receptor 1 (PD-1). Other hotspots for targeted therapies in the cells of HNSCC are sought after.

\section{Epidermal growth factor receptor}

EGFR, in other words ErbB1 or Herl is the most well-known and described cancer drug target. EGFR is a transmembrane protein that belongs to the ErbB/HER family of receptor tyrosine kinases (RTK) activity (12). Extracellular signals, which it transduces, are altered into intracellular responses, influencing cell proliferation, apoptosis, angiogenesis and the capacity of tumor cells to metastasize (12). Following binding the ligand [epidermal growth factor (EGF) or transforming growth factor $\alpha(\mathrm{TGF} \alpha)$ ], EGFR forms a homodimer or heterodimer with other members of the Erb family (ErbB2, ErbB3 and ErbB4) and activates the downstream signaling through the mitogen-activated protein kinases (MAPKs) cascade and the PI3K/AKT/mTOR pathway (13). This leads to the activation of certain genes in the cell nucleus, which promote angiogenesis, the formation of metastases $(13,14)$. EGFR overexpression can be determined in $~ 90 \%$ of HNSCC (8). It is considered to be a negative prognostic factor that increases the size of the tumor, reduces its radiosensitivity and increases the risk of its recurrence (8). In multivariate analysis, it was demonstrated that EGFR overexpression in patients with stages II-IV HNSCC, treated with standard radiation therapy, was associated with earlier relapse, reduced disease-free survival and overall survival (OS) $(13,14)$. Higher expression of the EGFR receptor is observed in well and moderately differentiated tumors [G1 and G2, according to the Broder's classification (15)], compared with high-grade tumors (G3) (16). Based on meta-analysis of 37 studies by Keren et al (17), EGFR expression was frequent in Austrian, Spanish and Dutch cohorts, in contrast to Swedish, French and Italian populations.

The inhibition of EGFR via targeted therapies is assisted by two types of molecules that differ slightly in the mode of action. The monoclonal anti-EGFR antibody binds to the extracellular domain of EGFR, preventing connections between ligands and thus interferes with the transmission of signals into the cell (18). Destruction of tumor cells is also carried out in the mechanism underlying antibody dependent cellular cytotoxicity (ADCC) $(14,18)$. Whereas the small molecules, EGFR tyrosine kinase inhibitors (TKIs), bind to the cytoplasmic region of EGFR by competing with adenosine-5'-triphosphate, and thereby inhibit the autophosphorylation of EGFR and signal transmission to the lower levels of the intracellular route (14). Further research on the EGFR gene is required. Due to the individual variable response to treatment with targeted therapies, there are various described mutations and polymorphisms of the EGFR gene, which may be a predictive factor for cancer therapy (19).

Cetuximab is a chimeric human immunoglobulin G1 antibody that binds to domain III of the extracellular region of EGFR $(12,20)$. Its effect on tumor cells is based on three different underlying mechanisms, which lead to the induction of apoptosis, inhibition of proliferation, angiogenesis and increase in the response to chemo- and radiotherapy (20). Cetuximab inhibits the phosphorylation of EGFR and transmission of signals to the cell, due to it preventing the attachment of other ligands via its direct binding to the receptor. Furthermore, it induces ADCC, which leads to the removal of coated cells with cetuximab (21). The result of the connection between cetuximab and EGFR may also be the internalization and reduction of the amount of cetuximab on the cell surface (21). The Agency for Food and Drug Administration (FDA) approved the use of cetuximab in cancer therapy in 2004 for the treatment of EGFR-expressing metastatic colon cancer resistant to irinotecan-based chemotherapy (22). After 4 years, in 2006 the FDA approved cetuximab in combination with radiotherapy for the treatment of locally advanced HNSCC on the basis of data were obtained from a multicenter phase III clinical trial (23). It demonstrated a statistically significant improvement in median OS in case of using radiotherapy plus cetuximab in comparison with radiation (49 and 29 months, respectively) in the initially untreated patients with stages III and IV without distant metastases (23).

Vermorken et al (24) demonstrated an increase in median OS by $\sim 3$ months and an increase in median progression-free survival (PFS) from 3.3 to 5.6 months in the group with cetuximab and chemotherapy, compared with the group with chemotherapy alone in metastatic or recurrent HNSCC. In 2008, based on the aforementioned trials, Cetuximab was approved by the FDA and European Medicines Agency, for locally advanced or metastatic HNSCC. Despite the improvement in treatment results obtained following the application of cetuximab with radiotherapy in the aforementioned trial, the addition of this monoclonal antibody to chemoradiotherapy based on cisplatin in locally advanced HNSCC did not improve the PFS in stages III and IV HNSCC (25).

An important predictor of locally advanced squamous cell carcinoma of the mouth and throat is human papilloma virus infection (HPV), which is determined by monoclonal antibodies directed against the P16 protein (p16). HPV containing the E7 gene causes the synthesis and increase in the level of p16 in infected cells. HPV positive tumors are characterized by a improved prognosis and a more favorable response to treatment. The NCT00047008 trial obtained 3-year survival in $87 \%$ of patients with detected HPV, compared with $57 \%$ of patients without such infection (26). There are ongoing phase III trials [Radiation Therapy Oncology Group (RTOG) 1016 and DE-ESCALATE] that compare treatments with cetuximab in combination with intensity modulated radiation therapy (IMRT) and the use of chemoradiotherapy with cisplatin in HPV-positive locally advanced squamous cell carcinoma of the oropharynx (27). It is noteworthy that despite the high EGFR expression in tumor cells of HNSCC, 
Table I. Examples of molecular-targeted therapies in the treatment of head and neck squamous cell carcinoma.

Mechanism of action

Molecular targeted therapy

EGFR monoclonal antibodies

EGFR tyrosine kinase inhibitors

VEGF inhibitors

VEGFR inhibitors

PI3K/AKT/mTOR pathway inhibitors

Anti-PD-1 antibodies
Cetuximab, panitumumab, zalutumumab and nimotuzumab

Gefitinib, erlotinib, lapatinib, afatinib and dacomitinib

Bevacizumab

Sorafenib, sunitinib and vandetanib

Rapamycin, temsirolimus, everolimus, torin1, PP242 and PP30

Pembrolizumab and nivolumab

EGFR, epidermal growth factor receptor; VEGF, vascular endothelial growth factor; VEGFR, VEGF receptor; PI3K, phosphatidylinositol 3-kinase; AKT, serine/threonine-specific protein kinase; mTOR, mammalian target of rapamycin; PD-1, programmed death receptor 1.

the response rate of cetuximab monotherapy ranges between $10-15 \%$ in the treatment of recurrent or metastatic stage of the disease (28). Currently, the only clinical predictor of cetuximab treatment is the severity of skin rash (29). The OS was extended to 68.8 months in patients with rash of grade 2 severity and higher, compared with 25.6 months in patients with rash of grades 0 and 1 severity (30). Therefore, there is a requirement to identify other responses of cancer cells to blocking with EGFR antibodies, as well as to overcome the immunity to such targeted therapies $(10,20)$.

The III variant of EGFR (EGFRvIII) is connected with deletion of 801 base pairs spanning exons 2-7 of the EGFR gene. It may occur in patients with HNSCC and it prevents the operation of cetuximab, as it is devoid of the extracellular domain (27). The clinical implications of the presence of EGFR vIII in HNSCC have not been evaluated in prospective clinical trials.

The trials conducted by RTOG indicate that patients with locally advanced carcinoma may benefit from a combination of cetuximab with docetaxel and concomitant radiotherapy. Another treatment option is the simultaneous administration of cetuximab and PI3K in HNSCC with a mutated PIK3CA gene (31). An indication to overcome the resistance to cetuximab can also be the extracellular signal-regulated kinase 1/2 (ERK1/2) inhibitors that disturb MAPK, which are activated in resistant tumor cells (32). The high expression of hepatocyte growth factor (HGF/MET) may serve a role in the resistance to cetuximab (33). Preclinical trials conducted on specific models with the use of HNSCC obtained a reduction of tumor growth following administration of crizotinib, a TKI HGF receptor (HGFR) (33).

Panitumumab is a completely human EGFR monoclonal antibody. It was approved by the FDA in the first-line treatment for patients diagnosed with metastatic colon cancer with the KRAS wild-type. Although, the randomized phase III trial (SPECTRUM) did not indicate any impact of the addition of panitumumab to chemotherapy on the OS of patients with recurrent and metastatic HNSCC, it demonstrated that the addition was associated with increased survival in p16-negative patients (34).

Other human EGFR antibodies include zalutumumab and nimotuzumab. The result of the phase III trial DAHANCA-19 (Danish Head and Neck Cancer Group) did not indicate any significant improvement in local and regional control and overall
OS following adding zalutumumab to the radiotherapy (35). Nimotuzumab has a promising effect in patients with advanced HNSCC (36). It is now being assessed in the phase III trial as treatment of locally and regionally advanced nasopharyngeal carcinoma (NCT02012062). The trial compares the effectiveness of nimotuzumab with cisplatin, both drugs are administered to patients during radiotherapy following preoperative chemotherapy according to the TPF (taxotere, cisplatin, 5-fluorouracil) scheme (NCT02012062) (37).

\section{Tyrosine kinase inhibitors}

None of the EGFR TKIs has been approved by the FDA for the treatment of HNSCC. These drugs are under review in clinical trials of phase II and phase III (38). Activity of TKIs in the treatment of non-small cell lung cancer is increased by somatic EGFR mutations as exon 19 deletion and the single-point substitution mutation L858R occurring more frequently in females and non-smokers (39). In HNSCC activating mutations are not so frequent but definitely require further study (40).

Gefitinib and erlotinib are the most common TKI, and are useful in the treatment of small cell lung carcinoma. The randomized phase III trial of the Eastern Cooperative Oncology Group demonstrated that the addition of gefitinib to docetaxel did not increase the toxicity of the treatment, but also did not improve the clinical outcome for patients with recurrent and metastatic HNSCC, compared with the use of docetaxel (27). However, it should be noted that patients who were previously heavily-treated or in a poor condition were included in the trial, and this may have had an effect on the data. The phase II trial, that used erlotinib with cisplatin and radiotherapy in the treatment of locally advanced HNSCC, obtained an improved response rate and improvement of the PFS, compared with the group with no antibodies (41).

Lapatinib is a TKI, which has specificity for EGFR (ErbB1). It also inhibits the ErbB2 receptor by the formation of a heterodimer. It is successfully used in the treatment of advanced breast cancer (42). The preliminary trials of it in the treatment of HNSCC have demonstrated its activity in the p-16 negative tumors in combination with chemoradiotherapy (43). A combination of lapatinib and capecitabine can be well-tolerated and active in the metastatic and recurrent forms of HNSCC (44). The ability of lapatinib to inhibit the 
two receptors can allow a break of the mechanisms underlying resistance to therapy aimed at EGFR antibodies through signal transduction (44).

Afatinib is an irreversible TKI that blocks the transmission of signals from all homo- and heterodimers formed by receptors of the ErbB family. It indicated an anti-proliferative and antitumor activity in pre-clinical cell models (45). It was registered in the first-line treatment of locally advanced or metastatic small cell lung carcinoma in patients with activating mutations in EGFR (46). The phase II trial indicated a comparable clinical efficacy of afatynib to cetuximab in recurrent HNSCC treated previously with chemotherapy based on platinum (47). It is evaluated in the phase III trial as an adjuvant following chemoradiotherapy in the treatment of unresectable advanced (stages III to IVa) HNSCC (48). One of the phase II trials determined that dacomitynib, another EGFR inhibitor, indicated clinical activity in the first-line treatment of recurrent or metastatic HNSCC (49).

\section{Vascular endothelial growth factor}

VEGF is a signaling protein produced by cells that stimulate angiogenesis (50). It is essential for the organism due to it is responsiblility for the formation of blood vessels during embryonic development, new blood vessels following injuries or a new capillary network that omits obstructed vessels (50). Hypoxia is a factor that induces the expression of VEGF (51). This happens in necrotic and hypoxic regions of tumor tissues (51). Therefore, overexpression of VEGF is present in the majority of HNSCC, consequently favoring tumor growth by changing the microvessel density in the vicinity of cells, cell migration and the formation of distant metastases (51). There is a growing evidence that the reduced sensitivity to radiation and progression of HNSCC is associated with stimulation of angiogenesis by tumor cells that undergo radiotherapy (52). The VEGF family is represented in mammals by five members: VEGF-A, placenta growth factor, VEGF-B, VEGF-C and VEGF-D (52).

There are several strategies aimed at VEGF, which are being evaluated in clinical trials and mediate the inhibition of angiogenesis (52). The most common molecules used in targeted therapies are: Bevacizumab, sorafenib, sunitinib and vandetanib (52). Bevacizumab is a humanized monoclonal antibody that targets VEGF-A. The antitumor therapy uses its ability to inhibit angiogenesis and to increase the delivery of chemotherapeutic agents to tumor cells by reducing microvascular permeability and reducing the pressure inside the tumor (20,52). It is also important that resistance is induced to anti-EGFR agents $(20,52)$. Bevacizumab was approved by the FDA for treatment of advanced cancer types, including colon cancer, kidney cancer, cervical cancer and brain cancer. Preclinical trials reported that bevacizumab has the ability to increase the sensitivity of HNSCC to radiotherapy. The mechanism underlying this phenomenon has not been fully understood. The paradoxical effect of hypoxia is explained by 'vascular normalization' (53). Bevacizumab temporarily lead to a decrease in interstitial fluid pressure and improvement in tumor oxygenation (53). Bevacizumab was evaluated in phase I and II clinical trials in combination with erlotinib in patients with recurrent or metastatic HNSCC $(54,55)$.
The results of these trials indicated that this treatment combination increased the complete response rate by $\sim 15 \%$ and median survival by 7.1 months (56). There are also trials that demonstrated the benefits of combining pemetrexed with bevacizumab (57). However, the phase II trial, which uses bevacizumab with cetuximab demonstrated no efficacy of this combination in recurrent HNSCC (NCT00409565) (58). The phase II trial, which added bevacizumab to a high dose of cisplatin with IMRT, produced encouraging results of efficacy in the treatment of stage III-IV B HNSCC (59). Researchers are currently waiting for the results of phase II trial on the combination of bevacizumab with chemotherapy, radiotherapy or EGFR inhibitors (NCT00968435) (60).

Sorafenib is a serine-threonine protein kinase inhibitor bRaf, C-Raf, VEGFR and platelet-derived growth factor receptor (PDGFR) (61). It was approved for treatment of advanced kidney cancer, advanced hepatocellular cancer and advanced thyroid cancer resistant to treatment with radioactive iodine (61). It is significant that it induces autophagy, which is a novel prospect of tumor therapy that inhibits tumor growth (61).

Preclinical trials indicated that sorafenib in combination with chemoradiotherapy may increase the antitumor effect by inhibiting cell growth, form cell clones, cell migration and cell invasion, compared with chemoradiotherapy or radiation without sorafenib $(62,63)$. By inhibiting the repair of double-stranded DNA breakages, sorafenib can be used to break the radio-resistance of HNSCC (64). The drug requires evaluation in other clinical trials.

Sunitinib is an oral, small molecule kinase inhibitor that targets VEGFR, PDGFR and c-Kit tyrosine kinase (65). It was approved by FDA for the treatment of renal cancer and imatinib-resistant gastrointestinal stromal tumors (65). Monotherapy with sunitinib demonstrated poor activity in the palliative treatment of HNSCC (65). However, the combination of cetuximab with sunitinib causes a reduction in tumor cell proliferation and an increase in their differentiation $(65,66)$.

Vandetanib is an oral kinase inhibitor targeted on EGFR, VEGFR-2 and the RTK. It was approved by the FDA for the treatment of metastatic medullary thyroid cancer in adult patients who are not candidates for surgery (67). The use of a combination of vandetanib and docetaxel in the treatment of small cell lung carcinoma indicated promising results (67). The use of vandetanib with cisplatin and radiotherapy has the ability to overcome the resistance to EGFR inhibitors in preclinical trials (68). The randomized phase II clinical trial, comparing the treatment of advanced HNSCC in stages III-IV with cisplatin and radiotherapy in combination with or without vandetanib, was prematurely terminated due to an insufficient number of patients to present significant results (NCT00720083) (69). Other VEGF inhibitors that are evaluated in clinical trials for the treatment of HNSCC include: Pazopanib, axitinib, nilotinib and linifanib (70-73).

\section{The PI3K/AKT/mTOR pathway}

The PI3K/AKT/mTOR pathway is an intracellular signaling pathway (74). The first signal of this pathway, that is PI3K can be activated in a number of ways. This is conducted by EGFR or insulin-like growth factor 1 receptor and by the 
adhesion of molecules, including integrins, $G$ protein-coupled receptors (GPCRs) and by oncogenes, including RAS (74). Stimulation of PI3K activates and phosphorylates AKT (74). The active AKT contributes to the downstream effects, including the activation of mTOR. mTOR is a key protein in the pathway (74). The PI3K/AKT/mTOR pathway serves an important role in the regulation of cell cycle, since it promotes the growth and proliferation more than differentiation of adult stem cells (74). Activation of this pathway was detected in numerous tumors and it causes a reduction of apoptosis of cancer cells and an increase of their proliferation (74). mTOR is a serine-threonine kinase. Its function is to regulate the cell cycle, cell survival and proliferation by monitoring the availability of nutrients, cellular energy level, cellular oxygenation and mitogenic signals (75). mTOR operates in two different protein complexes, including CREB-regulated transcription coactivator 1 (TORC1) and TORC2. mTOR is activated in tumors of the head and neck, and is an attractive therapeutic target (76). The expression level of mTOR and lower eukaryotic translation initiation factor 4E (eIF4E), eIF4E-binding protein 1 and ribosomal protein S6 kinase target molecules is a potential diagnostic and prognostic biomarker for tumors of the head and neck (76). There are two types of mTOR inhibitors. The first-generation inhibitors are derived from rapamycin, a macrolide antibiotic that is produced by Streptomyces hygroscopicus bacteria. Rapamycin forms a complex with the cytoplasmic protein peptidyl-prolyl cis-trans isomerase tacrolimus binding protein, which connects to mTOR (77). There are rapamycin analogues, which are used in humans, including temsirolimus and everolimus (77). The second generation MTOR inhibitors are ATP-competitive and include: Torin1, PP242 and PP30 (77). Little is known about them since they have not been evaluated in HNC clinical trials.

Temsirolimus is an intravenous drug that was approved by the FDA for the treatment of kidney cancer (78). The results of several trials performed in vitro on cell lines and in vivo on models of xenograft, demonstrated that temsirolimus inhibits proliferation of HNC (78-80). The trials with cell lines of squamous cell carcinoma of the head and neck indicated that the use of cetuximab in combination with mTOR inhibitors maybe beneficial in the treatment of tumors with high expression of EGFR or acquired resistance to cetuximab. This method of treatment requires further evaluation in clinical trials (81). The phase I clinical trial of temsirolimus and cetuximab in adult patients with advanced or metastatic solid tumors is in progress (NCT02215720) (82). Researchers are currently waiting for the results of phase I/II trial, which used temsiroliums in combination with the weekly administration of chemotherapy with paclitaxel and carboplatin in recurrent or metastatic HNSCC (NCT01016769) (83).

Everolimus is another mTOR inhibitor, which is used as an immunosuppressant to prevent organ transplant rejection and for the treatment of kidney cancer and other cancer types. There are several trials that demonstrated antitumor effect of everolimus for the treatment of HNSCC. Everolimus increased the antitumor effect of docetaxel in the model cell lines and xenografts (84). Currently, everolimus is being evaluated in several clinical trials. The randomized phase II trial compares everolimus to placebo in the adjuvant treatment of patients with locally advanced HNSCC (NCT01111058) (85).

\section{The PD}

PD-1 is an immunoreceptor and a negative regulator of the immune response (86). It is inducibly expressed on $\mathrm{T}$ and B lymphocytes, as well as the on dendritic cells and monocytes. The receptor is activated through binding with one of its ligands: PD-ligand 1 (PD-L1) or PD-L2 (86,87). As a result, the production of cytokines and proteins promoting cell survival diminishes, and synthesis of the interluekin-10 cytokines increases, contributing to the suppression of the inflammatory response $(86,87)$. A prolonged receptor stimulation with an antigen leads to an overexpression of PD-1 on the lymphocytes, which results in to impairment and the exhaustion of function $(86,87)$. The expression of PD-L1 has been proven in cancer cases involving the lungs, colon, stomach, kidneys, breasts, urinary bladder, head and neck and cases of melanoma. It results in a dysfunction of underlying anticancer mechanisms in tumor infiltrating lymphocytes and allows the tumor cells to go unnoticed by immune surveillance (87). The clinical potential of anti-PD-1 and anti-PD-L1 antibodies have been successfully employed in melanoma and lung cancer treatment (88). On August 5, 2016, pembrolizumab was granted accelerated approval by the FDA for patients with recurrent or metastatic HNSCC after platinum-containing chemotherapy. Pembrolizumab was given at $10 \mathrm{mg} / \mathrm{kg}$ every two weeks (Group 1) or 200 mg every 3 (Group 2) weeks intravenously. The objective response rate (ORR) and the complete response rates of Groups 1 and 2 were achieved in 16 and 5\% of patients, respectively. ORR was observed for six months for $>82 \%(23 / 28)$ of responding patients. These data did not depend on HPV status (89). In a phase III trial (NCT02358031), the efficacy of pembrolizumab in monotherapy, combined with standard chemotherapy based on platinum and 5-Fluorouracil for recurrence and/or metastasis HNSCC, compared with the standard forms of treatment. The control group of patients received standard chemotherapy based on platinum and cetuximab (90). At present this trial is ongoing, and its estimated completion date is January 2019.

Nivolumab is another anti-PD-L1 drug approved by FDA in November 2016 for patients with recurrent or metastatic HNSCC and disease progression $\leq 6$ months of receiving the platinum-based chemotherapy (91). The trial enrolled 361 patients randomized to nivolumab $3 \mathrm{mg} / \mathrm{kg}$ every 2 weeks intravenously or to investigator's choice of chemotherapy The investigator selected from one of the following drugs: Cetuximab; methotrexate; or docetaxel (92). The trial indicated a statistically significant difference and clinically significant improvement in OS in the nivolumab treatment arm [hazard ratio 0.7 (95\% CI: 0.52, 0.92); $\mathrm{P}=0.0101]$ (92). Estimated median OS was increased in nivolumab arm, compared with chemotherapy [7.5 months $(95 \% \mathrm{CI}=5.5,9.1)$ to 5.1 months (95\% CI=4, 6.0)] $(91,92)$.

\section{Other potential targeted therapies}

The activin receptor-like kinase-1 (ALK1) is a type I receptor belonging to TGF- $\beta$ and serves an essential role in modulating angiogenesis and the development of functional vasculature (92-94). Dalantercept (ACE-041) is a novel anti-angiogenic agent, which inhibits ALK1 signaling $(94,95)$. 
In contrast to other anti-angiogenic agents, ACE-041 does not block the proliferative phase of angiogenesis but it modulates the maturation phase of angiogenesis $(94,95)$.

The phase I study combined with results from preclinical pharmacology studies demonstrated that ACE-041 has a significant potential as an anticancer therapy in patients with advanced solid tumor types, including HNSCC $(94,96)$. The use of ACE-041 in patients with recurrent or metastatic HNSCC requires the results from a phase II clinical trial (NCT01458392) (96). Proteasomes are protein complexes that cause degradation of the proteins responsible for cell growth control. Inhibitors of proteasomes have demonstrated an anticancer activity by the induction of apoptosis and sensitization of malignant cells to conventional cytotoxic drugs (97).

Bortezomib is the first therapeutic proteasome inhibitor to be tested in humans and it is approved by FDA for treatment of relapsed multiple myeloma and mantle cell lymphoma (97). Preliminary results have demonstrated $50 \%$ disease control rates in patients with recurrent and metastatic HNSCC and the use of low-dose bortezomib (97). Notably, recent studies demonstrated that the combination of bortezomib with docetaxel, or with cetuximab and radiotherapy, may result in reduced PFS or OS $(98,99)$. GPCRs are the largest family of cell-surface molecules involved in signal transmission and their improved understanding may provide promising opportunities for drug discovery in cancer prevention and treatment $(100,101)$. The Notch signaling pathway is associated with multiple biologic functions, including regulation of self-renewal capacity, differentiation, cell-cycle exit and survival $(100,101)$. The Notch pathway may be a potential therapeutic target in the treatment of different types of cancer $(100,101)$. NOTCH1 mutations have been reported to occur in 10-15\% of HNSCC $(100,101)$. Increased activity of Notch has been observed in a number of cancer types (102). Notch inhibition can be conducted by inhibiting four receptors using $\gamma$-secretase inhibitors; however, they do not inhibit Notch activation but reduce the activity of further $\gamma$-secretase substrates (102). The tumor suppressor role of Notch signaling requires to be evaluated in further studies $(102,103)$.

\section{Conclusion}

The discovery of a novel class of cancer medication in the form of biopharmaceuticals led to personalized medicine, which is a novel approach to fighting cancer; however, the heterogeneity of molecular disorders in HNSCC still makes it difficult today to apply optimal, targeted strategies for its treatment. A number of biopharmaceuticals are currently being tested in clinical and preclinical trials; nonetheless, they have not revolutionized HNSCC treatment, and are not the standard treatment option. The identification of molecular markers, which are connected with the response to the treatment used, will help personalize targeted and non-targeted treatment. Ongoing genetic and molecular biology studies may render targeted therapy the fundamental method of cancer treatment in the future.

\section{Acknowledgements}

Not applicable.

\section{Funding}

No funding was received.

\section{Availability of data and materials}

All data generated and analyzed during this study are included in this published article.

\section{Authors' contributions}

PK and LGSZ designed the study and were responsible for the collection, analysis and interpretation of data in the literature. PK and LGSZ prepared the manuscript together and were involved in drafting the manuscript or revising it critically for important intellectual content. Both authors read and approved the final manuscript.

\section{Ethics approval and consent to participate}

Not applicable.

\section{Consent for publication}

Not applicable.

\section{Competing interests}

The authors declare that they have no competing interests.

\section{References}

1. Vigneswaran $\mathrm{N}$ and Williams MD: Epidemiologic trends in head and neck cancer and aids in diagnosis. Oral Maxillofac Surg Clin North Am 26: 123-141, 2014.

2. Macmillan Cancer Support: Types of head and neck cancer. https://www.macmillan.org.uk/information-andsupport/head-and-neck-cancers/understanding-cancer/types-headneck-cancer.html. Accessed Feb, 2016.

3. Hashibe M, Brennan P, Chuang SC, Boccia S, Castellsague X, Chen C, Curado MP, Dal Maso L, Daudt AW, Fabianova E, et al: Interaction between tobacco and alcohol use and the risk of head and neck cancer: Pooled analysis in the international head and neck cancer epidemiology consortium. Cancer Epidemiol Biomarkers Prev 18: 541-550, 2009.

4. Fung $C$ and Grandis JR: Emerging drugs to treat squamous cell carcinomas of the head and neck. Expert Opin Emerg Drugs 15: 355-373, 2010.

5. Adelstein D, Gillison ML, Pfister DG, Spencer S, Adkins D, Brizel DM, Burtness B, Busse PM, Caudell JJ, Cmelak AJ, et al: NCCN Guidelines insights: Head and neck cancers, version 2.2017. J Natl Compr Canc Netw 15: 761-770, 2017.

6. Brierley JD, Gospodarowicz MK and Wittekind $\mathrm{CH}$ : TNM Classification of Malignant Tumours Eighth Edition. Chichester, West Sussex, UK; Hoboken, NJ, John Wiley \& Sons, Inc., 2017.

7. Pignon JP, le Maitre A, Maillard E and Bourhis J; MACH-NC Collaborative Group: Meta-analysis of chemotherapy in head and neck cancer (MACH-NC): An update on 93 randomised trials and 17,346 patients. Radiother Oncol 92: 4-14, 2009.

8. Argiris A, Karamouzis MV, Raben D and Ferris RL: Head and neck cancer. Lancet 371: 1695-1709, 2008.

9. Suh Y, Amelio I, Guerrero Urbano T and Tavassoli M: Clinical update on cancer: Molecular oncology of head and neck cancer. Cell Death Dis 5: e1018, 2014.

10. Boeckx C, Baay M, Wouters A, Specenier P, Vermorken JB, Peeters $M$ and Lardon F: Anti-epidermal growth factor receptor therapy in head and neck squamous cell carcinoma: Focus on potential molecular mechanisms of drug resistance. Oncologist 18: 850-864, 2013. 
11. National Cancer Institute: NCI Dictionary of Cancer Terms: Definition of targeted therapy. https://www.cancer.gov/publications/dictionaries/cancer-terms?cdrid=270742. Accessed Feb, 2016.

12. Goerner M, Seiwert TY and Sudhoff H: Molecular targeted therapies in head and neck cancer-An update of recent developments. Head Neck Oncol 2: 8, 2010.

13. Song J, Chen C and Raben D: Emerging role of EGFR-Targeted therapies and radiation in head and neck cancer. Oncology (Williston Park) 18: 1757-1767, 1771-1772, 1777, 2004.

14. Lurje $\mathrm{G}$ and Lenz HJ: EGFR signaling and drug discovery. Oncology 77: 400-410, 2009

15. Schwab M (ed): Broder histological classification. In: Encyclopedia of Cancer. Berlin Heidelberg, Springer, 2011.

16. Alterio D, Marvaso G, Maffini F, Gandini S, Chiocca S, Ferrari A, Preda L, Rocca MC, Lepanto D, Fodor C, et al: Role of EGFR as prognostic factor in head and neck cancer patients treated with surgery and postoperative radiotherapy: Proposal of a new approach behind the EGFR overexpression. Med Oncol 34: 107, 2017.

17. Keren S, Shoude Z, Lu Z and Beibei Y: Role of EGFR as a prognostic factor for survival in head and neck cancer: A meta-analysis. Tumour Biol 35: 2285-2295, 2014.

18. Markovic A and Chung $\mathrm{CH}$ : Current role of EGF receptor monoclonal antibodies and tyrosine kinase inhibitors in the management of head and neck squamous cell carcinoma. Expert Rev Anticancer Ther 12: 1149-1159, 2012.

19. Obradović J, Djordjević N, Tošic N, Mrdjanović J, Stanković B, Stanić J, Zarić B, Perin B, Pavlović S and Jurišić V: Frequencies of EGFR single nucleotide polymorphisms in non-small cell lung cancer patients and healthy individuals in the Republic of Serbia: A preliminary study. Tumour Biol 37: 10479-10486, 2016.

20. Matta A and Ralhan R: Overview of current and future biologically based targeted therapies in head and neck squamous cell carcinoma. Head Neck Oncol 1: 6, 2009.

21. Huang SM and Harari PM: Modulation of radiation response after epidermal growth factor receptor blockade in squamous cell carcinomas: Inhibition of damage repair, cell cycle kinetics, and tumor angiogenesis. Clin Cancer Res 6: 2166-2174, 2000.

22. Cunningham D, Humblet Y, Siena S, Khayat D, Bleiberg H, Santoro A, Bets D, Mueser M, Harstrick A, Verslype C, et al: Cetuximab monotherapy and cetuximab plus irinotecan in irinotecan-refractory metastatic colorectal cancer. N Engl J Med 351: 337-345, 2004.

23. Bonner JA, Harari PM, Giralt J, Azarnia N, Shin DM, Cohen RB, Jones CU, Sur R, Raben D, Jassem J, et al: Radiotherapy plus cetuximab for squamous-cell carcinoma of the head and neck. N Engl J Med 354: 567-578, 2006.

24. Vermorken JB, Mesia R, Rivera F, Remenar E, Kawecki A, Rottey S, Erfan J, Zabolotnyy D, Kienzer HR, Cupissol D, et al: Platinum-based chemotherapy plus cetuximab in head and neck cancer. N Engl J Med 359: 1116-1127, 2008.

25. Ang KK, Zhang Q, Rosenthal DI, Nguyen-Tan PF, Sherman EJ Weber RS, Galvin JM, Bonner JA, Harris J, El-Naggar AK, et al: Randomized phase III trial of concurrent accelerated radiation plus cisplatin with or without cetuximab for stage III to IV head and neck carcinoma: RTOG 0522. J Clin Oncol 32: 2940-2950, 2014.

26. Ang KK, Harris J, Wheeler R, Weber R, Rosenthal DI, Nguyen-Tân PF, Westra WH, Chung CH, Jordan RC, Lu C, et al: Human papillomavirus and survival of patients with oropharyngeal cancer. N Engl J Med 363: 24-35, 2010.

27. Mirghani H, Amen F, Blanchard P, Moreau F, Guigay J, Hartl DM and Lacau St Guily J: Treatment de-escalation in HPV-positive oropharyngeal carcinoma: Ongoing trials, critical issues and perspectives. Int J Cancer 136: 1494-1503, 2015.

28. Van Damme N, Deron P, Van Roy N, Demetter P, Bols A Van Dorpe J, Baert F, Van Laethem JL, Speleman F, Pauwels P and Peeters M: Epidermal growth factor receptor and K-ras status in two cohorts of squamous cell carcinomas. BMC Cancer 10: 189,2010

29. Burtness B, Goldwasser MA,Flood W Mattar B and Forastiere AA; Eastern Cooperative Oncology Group: Phase III randomized tria of cisplatin plus placebo compared with cisplatin plus cetuximab in metastatic/recurrent head and neck cancer: An eastern cooperative oncology group study. J Clin Oncol 23: 8646-8654, 2005.

30. Bonner JA, Harari PM, Giralt J, Cohen RB, Jones CU, Sur RK, Raben D, Baselga J, Spencer SA, Zhu J, et al: Radiotherapy plus cetuximab for locoregionally advanced head and neck cancer: 5 -year survival data from a phase 3 randomised trial, and relation between cetuximab-induced rash and survival. Lancet Oncol 11: $21-28,2010$.
31. Wang Z, Martin D, Molinolo AA, Patel V, Iglesias-Bartolome R, Degese MS, Vitale-Cross L, Chen Q and Gutkind JS: mTOR co-targeting in cetuximab resistance in head and neck cancers harboring PIK3CA and RAS mutations. J Natl Cancer Inst 106: pii:dju215, 2014.

32. Boeckx C, Op de Beeck K, Wouters A, Deschoolmeester V, Limame R, Zwaenepoel K, Specenier P, Pauwels P, Vermorken JB, Peeters M, et al: Overcoming cetuximab resistance in HNSCC: The role of AURKB and DUSP proteins. Cancer Lett 354: 365-377, 2014

33. Knowles LM, Stabile LP, Egloff AM, Rothstein ME, Thomas SM, Gubish CT, Lerner EC, Seethala RR, Suzuki S, Quesnelle KM, et al: HGF and c-Met participate in paracrine tumorigenic pathways in head and neck squamous cell cancer. Clin Cancer Res 15: 3740-3750, 2009.

34. Vermorken JB, Stöhlmacher-Williams J, Davidenko I, Licitra L, Winquist E, Villanueva C, Foa P, Rottey S, Skladowski K, Tahara M, et al: Cisplatin and fluorouracil with or without panitumumab in patients with recurrent or metastatic squamous-cell carcinoma of the head and neck (SPECTRUM): An open-label phase 3 randomised trial. Lancet Oncol 14: 697-710, 2013.

35. Eriksen JG, Maare C, Johansen J, Primdahl H, Evensen J, Kristensen CA, Andersen LJ and Overgaard J: DAHANCA19: A randomized phase III study of primary (chemo-) radiotherapy and zalutumumab in head and neck carcinomas. ESTRO 33 Congress Report, pp11, 2014.

36. Sundaram S, Venkatanarayan B, Sridharan N and Poojar K: Nimotuzumab with induction chemotherapy and chemo-radiation in patients with advanced head and neck cancer. J Cancer Ther 6: 146-152, 2015

37. ClinicalTrials.gov: NCT02012062 phase III study of neoadjuvant TPF chemotherapy followed by radiotherapy and concurrent nimotuzumab or cisplatin for locoregionally advanced nasopharyngeal carcinoma (NPC). https://clinicaltrials. gov/ct2/show/NCT02012062. Accessed Sept, 2015.

38. Chapman CH, Saba NF and Yom SS: Targeting epidermal growth factor receptor for head and neck squamous cell carcinoma: Still lost in translation? Ann Transl Med 4: 80, 2016.

39. Kit OI, Vodolazhsky DI, Timoshkina NN, Vladimirova LY, Turkin IN, Kutsyn KA, Enin YS, Panina SB and Jurisic V: EGFR mutations and tumor metastases in patients with nonsmall cell lung cancer in the South of Russia. J BUON 22: 1410-1415, 2017.

40. Loeffler-Ragg J, Witsch-Baumgartner M, Tzankov A, Hilbe W, Schwentner I, Sprinzl GM, Utermann G and Zwierzina H: Low incidence of mutations in EGFR kinase domain in Caucasian patients with head and neck squamous cell carcinoma. Eur J Cancer 42: 109-111, 2006.

41. Martins RG, Parvathaneni U, Bauman JE, Sharma AK, Raez LE, Papagikos MA, Yunus F, Kurland BF, Eaton KD, Liao JJ, et al: Cisplatin and radiotherapy with or without erlotinib in locally advanced squamous cell carcinoma of the head and neck: A randomized phase II trial. J Clin Oncol 31: 1415-1421, 2013.

42. Fumagalli I, Dugue D, Bibault JE, Clémenson C, Vozenin MC, Mondini M and Deutsch E: Cytotoxic effect of lapatinib is restricted to human papillomavirus-positive head and neck squamous cell carcinoma cell lines. Onco Targets Ther 8: 335-345, 2015.

43. Harrington K, Berrier A, Robinson M, Remenar E, Housset M, de Mendoza FH, Fayette J, Mehanna H, El-Hariry I, Compton N, et al: Randomised Phase II study of oral lapatinib combined with chemoradiotherapy in patients with advanced squamous cell carcinoma of the head and neck: Rationale for future randomised trials in human papilloma virus-negative disease. Eur J Cancer 49: 1609-1618, 2013.

44. Weiss JM, Bagley S, Hwang WT, Bauml J, Olson JG, Cohen RB, Hayes DN and Langer C: Capecitabine and lapatinib for the first-line treatment of metastatic/recurrent head and neck squamous cell carcinoma. Cancer 122: 2350-2355, 2016.

45. Modjtahedi H, Cho BC, Michel MC and Solca F: A comprehensive review of the preclinical efficacy profile of the ErbB family blocker afatinib in cancer. Naunyn Schmiedebergs Arch Pharmacol 387: 505-521, 2014.

46. Sequist LV, Yang JC, Yamamoto N, O'Byrne K, Hirsh V, Mok T, Geater SL, Orlov S, Tsai CM, Boyer M, et al: Phase III study of afatinib or cisplatin plus pemetrexed in patients with metastatic lung adenocarcinoma with EGFR mutations. J Clin Oncol 31: 3327-3334, 2013.

47. Seiwert TY, Fayette J, Cupissol D, Del Campo JM, Clement PM, Hitt R, Degardin M, Zhang W, Blackman A, Ehrnrooth E and Cohen EE: A randomized, phase II study of afatinib versus cetuximab in metastatic or recurrent squamous cell carcinoma of the head and neck. Ann Oncol 25: 1813-1820, 2014. 
48. Burtness B, Bourhis JP, Vermorken JB, Harrington KJ and Cohen EE: Afatinib versus placebo as adjuvant therapy after chemoradiation in a double-blind, phase III study (LUX-Head \& Neck 2) in patients with primary unresected, clinically intermediate-to-high-risk head and neck cancer: Study protocol for a randomized controlled trial. Trials 15: 469, 2014.

49. Abdul Razak AR, Soulières D, Laurie SA, Hotte SJ, Singh S, Winquist E, Chia S, Le Tourneau C, Nguyen-Tan PF, Chen EX, et al: A phase II trial of dacomitinib, an oral pan-human EGF receptor (HER) inhibitor, as first-line treatment in recurrent and/or metastatic squamous-cell carcinoma of the head and neck. Ann Oncol 24: 761-769, 2013.

50. Hinerman RW, Mendenhall WM, Morris CG, Amdur RJ, Werning JW and Villaret DB: Postoperative irradiation for squamous cell carcinoma of the oral cavity: 35 year experience. Head Neck 26: 984-994, 2004

51. Minchenko A, Bauer T, Salceda S and Caro J: Hypoxic stimulation of vascular endothelial growth factor expression in vitro and in vivo. Lab Invest 3: 374-379, 1994.

52. Kyzas PA, Cunha IW and Ioannidis JP: Prognostic significance of vascular endothelial growth factor immunohistochemical expression in head and neck squamous cell carcinoma: A meta-analysis. Clin Cancer Res 11: 1434-1440, 2005.

53. Chen $\mathrm{Z}$ and $\mathrm{Xu} \mathrm{XH}$ : Combining antiangiogenic therapy and radiation in nasopharyngeal carcinoma. Saudi Med J 36: 659-664, 2015.

54. Vokes EE, Cohen EEW, Mauer AM, Karrison TG, Wong SJ, Skoog-Sluman LJ, Kozloff MF, Dancey J and Dekker A: A phase I study of erlotinib and bevacizumab for recurrent or metastatic squamous cell carcinoma of the head and neck (HNC). J Clin Oncol 23 (Suppl 16): S5504, 2005.

55. Burtness B: Commentary Bevacizumab and erlotinib with chemoradiation for head and neck cancer. Cancer J 17: 273-275, 2011.

56. Cohen EE, Davis DW, Karrison TG, Seiwert TY, Wong SJ, Nattam S, Kozloff MF, Clark JI, Yan DH, Liu W, et al: Erlotinib and bevacizumab in patients with recurrent or metastatic squamous-cell carcinoma of the head and neck: A phase I/II study. Lancet Oncol 3: 247-257, 2009

57. Feinstein T, Raez L, Rajasenan K, Gibson MK, Savvides P Karamouzis MV, Garg N, Johnson R, Branstetter BF and Argiris AE: Pemetrexed (P) and bevacizumab (B) in patients (pts) with recurrent or metastatic head and neck squamous cell carcinoma (HNSCC): Updated results of a Phase II trial. J Clin Oncol 26 (15 Suppl): S6069, 2008.

58. Argiris A, Kotsakis AP, Hoang T, Worden FP, Savvides P, Gibson MK, Gyanchandani R, Blumenschein GR Jr, Chen HX, Grandis JR, et al: Cetuximab and bevacizumab: Preclinical data and phase II trial in recurrent or metastatic squamous cell carcinoma of the head and neck. Ann Oncol 24: 220-225, 2013.

59. Fury MG, Lee NY, Sherman E, Lisa D, Kelly K, Lipson B, Carlson D, Stambuk H, Haque S, Shen R, et al: A phase 2 study of bevacizumab with cisplatin plus intensity-modulated radiation therapy for stage III/IVB head and neck squamous cell cancer. Cancer 15: 5008-5014, 2012

60. ClinicalTrials.gov: NCT00968435 Bevacizumab, Cetuximab, and cisplatin with IMRT (Intensity-Modulated Radiation Therapy) for patients with stage III/IV head and neck squamous cell carcinoma. https://clinicaltrials.gov/ct2/show/NCT00968435/. Accessed Jun, 2016.

61. Zhang Y, Xue D, Wang X, Lu M, Gao B and Qiao X: Screening of kinase inhibitors targeting BRAF for regulating autophagy based on kinase pathways. Mol Med Rep 9: 83-90, 2014.

62. Yadav A, Kumar B, Teknos TN and Kumar P: Sorafenib enhances the antitumor effects of chemoradiation treatment by downregulating ERCC-1 and XRCC-1 DNA repair proteins. Mol Cancer Ther 10: 1241-1251, 2011.

63. Möckelmann N, Rieckmann T, Busch CJ, Becker B, Gleissner L, Hoffer K, Omniczynski M, Steinmeister L, Laban S, Grénman R, et al: Effect of sorafenib on cisplatin-based chemoradiation in head and neck cancer cells. Oncotarget 7: 23542-23551, 2016.

64. Laban S, Steinmeister L, Gleissner L, Grob TJ, Grénman R, Petersen C, Gal A, Knecht R, Dikomey E and Kriegs M: Sorafenib sensitizes head and neck squamous cell carcinoma cells to ionizing radiation. Radiother Oncol 109: 286-292, 2013.

65. Bozec A, Sudaka A, Toussan N, Fischel JL, Etienne-Grimaldi MC and Milano G: Combination of sunitinib, cetuximab and irradiation in an orthotopic head and neck cancer model. Ann Oncol 20: 1703-1707, 2009.
66. Machiels JP, Henry S, Zanetta S, Kaminsky MC, Michoux N, Rommel D, Schmitz S, Bompas E, Dillies AF, Faivre S, et al: Phase II study of sunitinib in recurrent or metastatic squamous cell carcinoma of the head and neck: GORTEC 2006-01. J Clin Oncol 28: 21-28, 2010.

67. Heymach JV, Johnson BE, Prager D, Csada E, Roubec J, Pesek M, Spásová I, Belani CP, Bodrogi I, Gadgeel S, et al: Randomized, placebo-controlled phase II study of vandetanib plus docetaxel in previously treated non small-cell lung cancer. J Clin Oncol 25: 4270-4277, 2007.

68. Papadimitrakopoulou VA, Frank SJ, Cohen EW, Hirsch FR, Myers JN, Heymach JV, Lin H, Tran HT, Chen CR, Jimeno A, et al: Phase I study of vandetanib with radiation therapy with or without cisplatin in locally advanced head and neck squamous cell carcinoma. Head Neck 38: 439-447, 2016.

69. Hsu HW, Wall NR, Hsueh CT, Kim S, Ferris RL, Chen CS and Mirshahidi S: Combination antiangiogenic therapy and radiation in head and neck cancers. Oral Oncol 50: 19-26, 2014

70. Brands RC, Knierim LM, De Donno F, Steinacker V, Hartmann S, Seher A, Kübler AC and Müller-Richter UD: Targeting VEGFR and FGFR in head and neck squamous cell carcinoma in vitro. Oncol Rep 38: 1877-1885, 2017.

71. Swiecicki PL, Zhao L, Belile E, Sacco AG, Chepeha DB, Dobrosotskaya I, Spector M, Shuman A, Malloy K, Moyer J, et al: A phase II study evaluating axitinib in patients with unresectable, recurrent or metastatic head and neck cancer. Invest New Drugs 33: 1248-1256, 2015.

72. Hsu HW de Necochea-Campion R Williams V Duerksen-Hughes PJ, Simental AA Jr, Ferris RL, Chen CS and Mirshahidi S: Linifanib (ABT-869), enhances cytotoxicity with poly (ADP-ribose) polymerase inhibitor, veliparib (ABT-888), in head and neck carcinoma cells. Oral Oncol 50: 662-669, 2014.

73. Kramer B, Hock C, Birk R, Sauter A, Stuck BA, Hörmann K, Schultz JD and Aderhold C: Targeted therapies in HPV-positive and -negative HNSCC-Alteration of EGFR and VEGFR-2 expression in vitro. Anticancer Res 36: 2799-2807, 2016.

74. LoPiccolo J, Blumenthal GM, Bernstein WB and Dennis PA: Targeting the PI3K/Akt/mTOR pathway: Effective combinations and clinical considerations. Drug Resist Updat 11: 32-50, 2008.

75. Liu P, Cheng H, Roberts TM and Zhao JJ: Targeting the phosphoinositide 3-kinase pathway in cancer. Nat Rev Drug Discov 8: 627-644, 2009.

76. Lionello M, Blandamura S, Loreggian L, Ottaviano G, Giacomelli L, Marchese-Ragona R, Velardita C, Staffieri A and Marioni G: High mTOR expression is associated with a worse oncological outcome in laryngeal carcinoma treated with postoperative radiotherapy: A pilot study. J Oral Pathol Med 41: 136-140, 2012

77. Zaytseva YY, Valentino JD, Gulhati P and Evers BM: mTOR inhibitors in cancer therapy. Cancer Lett 319: 1-7, 2012.

78. Schedel F, Pries R, Thode B, Wollmann B, Wulff S, Jocham D, Wollenberg B and Kausch I: mTOR inhibitors show promising in vitro activity in bladder cancer and head and neck squamous cell carcinoma. Oncol Rep 25: 763-768, 2011.

79. Nathan CO, Amirghahari N, Rong X, Giordano T, Sibley D, Nordberg M, Glass J, Agarwal A and Caldito G: Mammalian target of rapamycin inhibitors as possible adjuvant therapy for microscopic residual disease in head and neck squamous cell cancer. Cancer Res 67: 2160-2168, 2007.

80. Bauman JE, Arias-Pulido H, Lee SJ, Fekrazad MH, Ozawa H, Fertig E, Howard J, Bishop J, Wang H, Olson GT, et al: A phase II study of temsirolimus and erlotinib in patients with recurrent and/or metastatic, platinum-refractory head and neck squamous cell carcinoma. Oral Oncol 49: 461-467, 2013.

81. Niehr F, Weichert W, Stenzinger A, Budach V and Tinhofer I: CCI-779 (Temsirolimus) exhibits increased antitumor activity in low EGFR expressing HNSCC cell lines and is effective in cells with acquired resistance to cisplatin or cetuximab. J Transl Med 13: 106, 2015.

82. Hollebecque A, Bahleda R, Faivre L, Adam J, Poinsignon V, Paci A, Gomez-Roca C, Thery JC, Le Deley MC, Varga A, et al: Phase I study of temsirolimus in combination with cetuximab in patients with advanced solid tumors. Eur J Cancer 81: 81-89, 2017.

83. Li SH, Lin WC, Huang TL, Chen CH, Chiu TJ, Fang FM, Huang WT, Hsu CM, Luo SD, Lai CC, et al: Significance of mammalian target of rapamycin in patients with locally advanced stage IV head and neck squamous cell carcinoma receiving induction chemotherapy with docetaxel, cisplatin, and fluorouracil. Head Neck 38 (Suppl 1): E844-E852, 2016. 
84.ClinicalTrials.gov: NCT01016769 temsirolimus + weekly paclitaxel + carboplatin for recurrent or metastatic head and neck squamous cell cancer (HNSCC). https://clinicaltrials. gov/ct2/show/NCT01016769. Accessed Feb, 2016.

85. ClinicalTrials.gov. Everolimus versus placebo in head and neck cancer. https://clinicaltrials.gov/ct2/show/NCT01111058. Accessed $20 \mathrm{Feb}, 2016$.

86. Grzywnowicz M and Giannopoulos K: The role of receptor programmed death-1 and its ligands in immune system and tumors. Acta Haematol Pol 43: 132-145, 2012.

87. Dong H, Zhu G, Tamada K and Chen L: B7-H1, a third member of the B7 family, co-stimulates T-cell proliferation and interleukin-10 secretion. Nat Med 5: 1365-1369, 1999.

88. Hamid O, Robert C, Daud A, Hodi FS, Hwu WJ, Kefford R Wolchok JD, Hersey P, Joseph RW, Weber JS, et al: Safety and tumor responses with lambrolizumab (anti-PD-1) in melanoma. N Engl J Med 2369: 134-144, 2013.

89. Mehra R, Seiwert TY, Mahipal A, Weiss J, Berger R, Eder JP, Burtness B, Tahara M, Keam B, Dung LE, et al: Efficacy and safety of pembrolizumab in recurrent/metastatic head and neck squamous cell carcinoma (R/M HNSCC): Pooled analyses after long-term follow-up in KEYNOTE-012. J Clin Oncol 34 (Suppl 15): S6012, 2016.

90.ClinicalTrials.gov: NCT02358031 a study of pembrolizumab (MK-3475) for first line treatment of recurrent or metastatic squamous cell cancer of the head and neck (MK-3475-048/KEYNOTE-048). https://clinicaltrials. gov/ct2/show/NCT02358031. Accessed Jun, 2016.

91. Ferris RL, Blumenschein GR, Fayette J, Guigay J, Colevas D, Licitra L, Harrington K, Kasper S, Vokes EE, Even C, et al: Further evaluations of nivolumab (nivo) versus investigator's choice (IC) chemotherapy for recurrent or metastatic (R/M) squamous cell carcinoma of the head and neck (SCCHN): CheckMate 141. J Clin Oncol 34 (Suppl 15): S6009, 2016.

92. Ferris RL, Blumenschein GR, Fayette J, Guigay J, Colevas D, Licitra L, Harrington K, Kasper S, Vokes EE, Even C, et al: Nivolumab for recurrent Squamous-cell carcinoma of the head and neck. N Engl J Med 375: 1856-1867, 2016.

93. Seki T, Yun J and Oh SP: Arterial endothelium-specific activin receptor-likekinase 1 expression suggests its role in arterialization and vascular remodeling. Circ Res 93: 682-689, 2003.

94. Cunha SI and Pietras K: ALK1 as an emerging target for antiangiogenic therapy of cancer. Blood 117: 6999-7006, 2011.

95. Clinical Trials.gov: NCT01458392 Study of Dalantercept in Patients with squamous cell carcinoma of the head and neck https://clinicaltrials.gov/ct2/show/NCT01458392. Accessed Jun, 2016.
96. Hawinkels LJ, de Vinuesa AG, Paauwe M, Kruithof-de Julio M, Wiercinska E, Pardali E, Mezzanotte L, Keereweer S, Braumuller TM, Heijkants RC, et al: Activin Receptor-like kinase 1 ligand trap reduces microvascular density and improves chemotherapy efficiency to various solid tumors. Clin Cancer Res 22: 96-106, 2016

97. Dudek AZ, Lesniewski-Kmak K, Shehadeh NJ, Pandey ON, Franklin M, Kratzke RA, Greeno EW and Kumar P: Phase I study of bortezomib and cetuximab in patients with solid tumours expressing epidermal growth factor receptor. Br J Cancer 100: 1379-1384, 2009.

98. Chung CH, Aulino J, Muldowney NJ, Hatakeyama H, Baumann J, Burkey B, Netterville J, Sinard R, Yarbrough WG, Cmelak AJ, et al: Nuclear factor-kappa B pathway and response in bortezomib and docetaxel in patients with recurrent and/or metastatic head and neck squamous cell carcinoma. Ann Oncol 21: 864-870, 2010.

99. Argiris A, Duffy AG, Kummar S, Simone NL, Arai Y, Kim SW Rudy SF, Kannabiran VR, Yang X, Jang M, et al: Early tumor progression associated with enhanced EGFR signaling with bortezomib, cetuximab and radiotherapy for head and neck cancer. Clin Cancer Res 17: 5755-5764, 2011

100. Agrawal N, Frederick MJ, Pickering CR, Bettegowda C, Chang K, Li RJ, Fakhry C, Xie TX, Zhang J, Wang J, et al: Exome sequencing of head and neck squamous cell carcinoma reveals inactivating mutations in NOTCH1. Science 333: 1154-1157, 2011

101. Sun W, Gaykalova DA, Ochs MF, Mambo E, Arnaoutakis D, Liu Y, Loyo M, Agrawal N, Howard J, Li R, et al: Activation of the NOTCH pathway in Head and Neck cancer. Cancer Res 74: 1091-1104, 2014.

102. Platonova N, Lesma E, Basile A, Bignotto M, Garavelli S, Palano MT, Moschini A, Neri A, Colombo $M$ and Chiaramonte R: Targeting Notch as a therapeutic approach for human malignancies. Curr Pharm Des 23: 108-134, 2017.

103. Platonova N, Parravicini C, Sensi C, Paoli A, Colombo M, Neri A, Eberini I and Chiaramonte R: Identification of small molecules uncoupling the Notch: Jagged interaction through an integrated high-throughput screening. PLoS One 12: e0182640, 2017. 